\title{
The Role of Homestead Agroforestry Practice on the Climate Change Adaptation and Mitigation: A Review
}

\begin{abstract}
Abdi Hassen Abdula
East Hararghe, Meta Agricultural Office, College of Agriculture and Environmental Sciences, Africa Center of Excellence for Climate Smart Agriculture and Biodiversity Conservation, Department of climate smart agriculture, Haramaya University, Haramaya, Oromia, Ethiopia.
\end{abstract}

How to cite this paper: Abdi Hassen Abdula. (2021) The Role of Homestead Agroforestry Practice on the Climate Change Adaptation and Mitigation: A Review. International Journal of Food Science and Agriculture, 5(4), 617-622. DOI: $10.26855 /$ ijfsa.2021.12.008

Received: September 8, 2021

Accepted: October 2, 2021

Published: October 27, 2021

*Corresponding author: Abdi Hassen Abdula, East Hararghe, Meta Agricultural Office, College of Agriculture and Environmental Sciences, Africa Center of Excellence for Climate Smart Agriculture and Biodiversity Conservation, Department of climate smart agriculture, Haramaya University, Haramaya, Oromia, Ethiopia.

Email: abd51042@gmaail.com

\begin{abstract}
Homestead, the home and adjacent grounds occupied by a family, is the potential production area. Homestead agroforestry is popularly called homestead production system. It is the integrated production of crops, trees, and livestock in the household's residence and its surrounding areas. This review explores diversity of homestead agro-forests together with their advantages to the adaptation and climate change mitigation. It was revealed that homestead owners of householders were more positive attitude towards climate change adaptation in homestead production system. Due to climate change, there were several crops and various types of vegetables with multipurpose tree species such as Mango, Jackfruit, Mehogoni, Coconut, Raintree and Mehogoni, are practiced in homestead agroforestry along with the annual crops subjected to change of planting dates over time. Homestead agro-forests thus meet the conditions to be a clean development mechanism agroforestry practice, which would develop as strategy for small-scale farmers in climate change mitigation and adaptation initiatives, and biodiversity conservation. The reviews show that homestead agroforestry has a lot of contribution to reduce the problems of climate change and enhance a building resilience to climate change. Therefore, the development of homestead agroforestry practice, also contributes to economic purpose in additions to climate change mitigation and adaptations.
\end{abstract}

\section{Keywords}

Climate Change, Adaptation and Mitigation

\section{Introduction}

Global warming is caused by an increase in the amount of greenhouse gases (GHG) in the atmosphere, mostly carbon dioxide (CO2), methane (CH4), and nitrous oxide (N2O), which trap infrared radiation and prevent it from escaping into space [1]. Agro-forest ecosystems, which are deemed to be an important factor in climate change, can be managed to assimilate $\mathrm{CO} 2$ via photosynthesis and store carbon in biomass and in the soil [2]. Tropical forests make up $80 \%$ of the earth's total forests. The agro-forests have the greatest long-term potential to sequester atmospheric carbon by protecting forested lands, slowing deforestation, and by means of reforestation [3].

People in rural and semi-urban areas of country, plant and maintain a wide variety plants in their homesteads. They have intentionally been growing these plants for generations for meeting household needs including fuel wood, timber, fruit and vegetables, as well as for revenue and environmental amelioration. In the face of rapid degradation of public 
forests of the country, these homestead forests are considered as major supplier of forest products. Tropical homestead agro forestry has potential for carbon sequestration and can help to mitigate climate change impacts [4]. Homestead agro forestry, that integrates tree production with crop and animal production, is believed to have a higher potential to sequester carbon in pastures or field crops [5]. It also helps to reduce carbon emissions from fossil-fuel burning through fuel wood production and conservation of carbon stocks in existing agro forestry by alleviating pressure on these forests [6].

The significance of homestead agro forestry to reduce green house gases emission is well appreciated throughout the world. There has to more research on the role of homesteads agro forestry practice in relation to policies and measures to mitigate against and adapt to climatic change [7]. Therefore, this review was carried out to express the importance of the homestead agro forestry practice to mitigate climate change and enhance adaptation.

\subsection{Objectives}

General objectives

* Reviews on the role of homesteads agro forestry practice in the climate change adaptations and mitigations

Specific objectives

$>$ To reviews on the purpose of homestead agro forestry practice adaptation in response to climate change

$>$ To reviews on the advantage of homestead agro forestry practice in the climate change mitigations

\section{The Role of Homesteads Agroforestry Practice in the Climate Change Adaptations and Mi- tigations}

\subsection{Definitions, concept and importance of homestead agro forestry practice}

Homestead agroforestry, which is popularly called homestead production system or home gardening of the integrated production of crops, trees, and/or livestock in the household's residence and its surrounding areas. Homestead agro forestry includes mixed plantings of annual, tree crops and pasture around dwelling area, which is a common type of multistoried agro forestry system. The farmers grow multipurpose trees in their home gardens for flowers, fruits, and seeds, trees, fish, agricultural crops, cattle [8]. The homestead owners themselves consume a large proportion of the products and the rest of the products are sold in the market. The homestead systems contribute about 70 percent fruit, 40 percent vegetables, 70 percent timber and 90 percent firewood and bamboo requirement of the country. Due to shortage of agricultural land, homestead agro forestry practice may be a good strategy for survival and existence of the farmers by attaining food and income security [9].

The agroforestry practices include homestead agro forestry, cropland agro forestry and woodlot. The annual crops cultivated in the homestead agro forestry are various types of vegetables with multipurpose tree species like Mango, Jackfruit, Mehogoni, Coconut, Raintree, Mehogoni, are practiced in different types of Cropland agro forestry along with the annual crops like paddy, sugarcane [10]. As assemblages and repositories of a vast number of plants in small parcels of land around the home in direct and constant interaction with their owners, homestead forests fulfill the specific economic, social, and cultural needs of the individual owners and provide biological conservation, carbon storage and other intangible, yet valuable, benefits to society. With their ecological similarity to natural forest ecosystems, homestead forests act as an insurance against pest infestations and disease outbreaks [11].

Homestead agroforestry systems are most appropriate for resource poor farmers. They can earn immediate benefits from crops while waiting for long term benefits from trees. A unique combination of different species of fruit, timber and biomass yielding trees can generate high amount of earnings for the farmers [12]. Most of the trees in homestead agro forestry system to be traditional varieties with less production potential. So, there is much scope to improve productivity of the system both in the homesteads and in the fields by replacing the existing tree species/varieties with the improved ones, planting trees in planned ways, using suitable tree-crop combination and by improving management practices [13]. Homestead agroforestry that integrates tree production with crop and animal production is believed to have a higher potential to sequester carbon than pastures or field crops [5]. It also helps to reduce carbon emissions from fossil-fuel burning through fuel wood production and conservation of carbon stocks in existing natural forests by alleviating pressure on these forests $[6,11]$. Overall, home gardens reduce atmospheric carbon dioxide through carbon sequestration, carbon conservation and carbon substitution [5].

\subsection{Trees grown in the homestead agro forestry to adaptation and mitigate climate change}

Farmers usually prefers Multi Purpose Trees (MPTs) which simply fruit, fodder, fuel wood and timber to meet their day to day requirement, as well as for sale to generate cash as a regular source of income and also to tide over emergent needs. Homestead agroforestry is mainly silvo-horticultural and silvo-pastural system where major agricultural crops 
are very rare. The plants grown in the homesteads are broadly classified into food (fruits, vegetables, spices), timber and fuel wood, medicinal, and ornamental species [14].

The predominant trees planted in homestead are universally mango and jackfruit which are used for fruit as well as timber; the latter species is also highly valued for forage, particularly for goat rearing. The most intensive tree cropping system is found homestead agroforestry or small farms based on a close association of coconut, kitul, and betel palms with cloves, cinnamon, nutmeg, citrus, mango, durian, jackfruit and breadfruit, with a lower storey of bananas and pepper vines, and a peripheral ground storey of maize, cassava, beans, and pineapples, are practiced [8]

\subsection{Species and Vegetables grown in the homestead agro forestry}

Majority of the vegetable and fruit produced in the different country are coming from the homesteads agro forestry [15]. Different types of vegetables and spices are found to grow in the homestead agro forestry by all categories of farmer round the year in a small scale, mostly for their own consumption. Vegetables are grown in three types of micro-sites within the homestead viz. in shady place, in open place and creeping on the tree and adapting to local community to mitigate climate change and food security [16].

\subsection{Adaptation role of homestead agro forestry}

Adaptation to climate change involves monitoring and anticipating change and undertaking actions to avoid the negative consequences and to take advantage of potential benefits of those changes. Adaptation to climate change requires combining scientific knowledge with indigenous knowledge and practices [17]. Moreover, adaptation to climate change needs to be a continuous attempt. Use of indigenous knowledge and local coping strategies should be promoted as a starting point for planning climate change mitigation and adaptation [18]. However, the ability of communities to adapt to the impacts of climate variability and change, Adaptation to climate is the process through which people reduce the adverse effects of climate on their health and well-being and take advantage of the opportunities that their climatic environment provides. It is one of the policy options for reducing the negative impacts of climate changes. It also refers to the degree to which adjustments are possible in practices, processes, or structures of systems to projected or actual changes of climate [19]. Adaptation refers to adjustment in systems in response to actual or expected climatic effects, which moderates harm or exploits beneficial opportunities. The main goals of climate change adaptation are to reduce vulnerability and build resilience to the impacts brought by climate change [20].

\subsubsection{To maximize homestead agro forestry resources for enhancing adaptive and resilience capacity of commu- nity people}

By planting and nursing some productive but extreme climate tolerant species and saplings including native vegetations with an elevated mood and ditch structure. Integrated approach of planting fruit trees, timber trees, herbs, shrubs, plants, vegetables, pond fisheries, agrosilviculture, animal husbandry, with a goal to establish a 'Green Zone' in the some selected climate affected vulnerable communities. Villagers' opinions on choice of species reveal that they choose plants for multiple purposes, including economic and environmental values. Their local knowledge on planting light canopy fruit species near dwelling and large canopy taller trees on boundaries has productive and protective functions [21]. Boundary trees act as a wind barrier and protect trees and houses downwind. Villagers can take intensive and regular care of trees near to houses and can protect fruit from pilferage. In order to reduce the extent of cyclone damage, villagers build houses at the centre of homestead land, surrounded by tree [16].

\subsubsection{Strategies of Community based climate adaptation on the homestead agro forestry practice}

Existing coping mechanisms and capacities are recognized community based climate adaptation builds upon and strengthen existing coping strategies and capacities; most common social and organizational values and mechanism are cooperation, community people's organizations, local knowledge and resources. Farming communities have accumulated considerable experiences for living with climate risks over time and have developed a range of adaptation strategies. Capacity building in climate adaptation, sustained education and training activities; sustained public awareness etc. be linked with available agro forest resources [22]. Community based climate response organization climate management teams, climate response committee, climate management committee; climate management network can be engaged in mobilizing the on homestead agro forestry /village forest resources. Counter climate plan, i.e., emergency and contingency plan; counter preparedness and mitigation plan; community development plan etc. can also be linked with local forests resources [23].

$>$ Climate Risk Reduction

$>$ Partnerships in Climate Risk Reduction

$>$ partnerships of the vulnerable sectors with less vulnerable groups

> partnerships of the community with local government and other communities can also be developed for sustainable regeneration and utilization of forest resources 
Specific Climate Adaptation options plan in the context of homestead agro forestry

$>$ Introduction of co-management in developing homestead forestry to address the adverse effect of climate change

\subsection{Climate change mitigation in the homestead agro forestry practice}

Climate change mitigation is a human intervention to reduce the sources or enhance the sinks of greenhouse gases [24]. Appropriate activities related to agro forestry can help reduce GHG concentrations in the atmosphere by increasing biotic carbon storage, decreasing GHG emissions from operations, and producing biomass as a substitute for fossil fuels [25]. The first option is to reduce the consumption of fossil fuels, thereby reducing GHG emissions; the second one is to maintain and/or increase the vegetation cover, thereby enhancing carbon sinks (carbon sequestration). Thus, climate change mitigation measures reduce the concentrations of GHGs in the atmosphere. Tropical homestead forests, often called home gardens and homestead agro forestry, have potential for carbon sequestration and can help to mitigate climate change impacts [4].

\subsubsection{Homestead agro forest of Carbon financing to mitigate climate change}

Sequestration of atmospheric carbon by homestead agro forests is well recognized as a low-cost mitigation measure for greenhouse gas [26]. A number of carbon-sink-related clean development mechanism (CDM) forestry projects have been promoted around the globe for the promotion of sustainable development, conservation of agro forests and mitigation of climate change. However, none of these CDM forestry projects include homestead agro forests, implying that the potential of these forests as a strategy for carbon sequestration has not yet been fully recognized even though they offer considerable scope to improve biomass accumulation and economic efficiency of climate change mitigation [4].

Villagers have managed these homestead agro forests sustainably for generations and there are no land property rights problems because they established forests on their personal land. There is scope to increase tree numbers by planting woody trees along boundaries to increase carbon sequestration. Overall, it seems that homestead agro forests are permanent, do not face land tenure conflicts and have potential for increased carbon sequestration. Homestead forests are small in size and it would not be easy to motivate all villagers or urban and peri-urban. However, this requires extensive coordination, collaboration and consensus [27, 28].

\subsubsection{Choice of Species for mitigation of natural hazards from climate change}

The frequent natural hazards including seasonal cyclones, tidal storms and sea water surges that are increasing in frequency and cause damage to houses, soil erosion, salinity intrusion and vegetation damage [21]. Many homesteads agroforestry have become permanently inundated and villagers suspect that in future it would be very difficult for them to survive. High survival rate of these species (85\%), strong root system that protects plants from uprooting during cyclones (72\%), strong stems which do not break easily (68\%), and low weight associated with light canopy which reduces wind load on trees (55\%) thus prevents houses from wind damage. The wind speed is reduced when wind hits the trees and hence the destructive force of strong wind declines. Trees with a taproot or sufficient branch roots retain upright growth and can survive well against heavy wind [29].

\subsubsection{Potential role of homesteads in carbon sequestration to mitigate climate change}

The carbon sequestered within agro-forestry systems may have a positive impact on the global GHG balance. Most tree species in homestead are slow growing and long lived. They can also form a large canopy volume with a high total car-bon accumulation. An example is Ficus, one of the most prominent canopy species, which is a slow growing tree that can attain a large size, has a higher carbon density, and can be credited with sequestering a maximum total carbon. The wood is used for fuel, construction, and/or farm implements [30]. Whole tree harvest is uncommon in the management of this type of system; thus, the carbon sequestered stays there over a long period of time and critical role in climate change mitigation. It has been reported that forest carbon stock can be estimated as $50 \%$ (dry mass basis) of above ground Biomass [31]. Using this approximation it can be assumed that mean carbon stock across the three study sites is $117.73 \mathrm{Mg} \mathrm{C} / \mathrm{ha}$, which is nearly twice as much as the mean Above ground biomass carbon stock (61 Mg C/ha) reported in homestead agro forests [6]. The average aboveground standing stocks of carbon in home gardens ranged from 16 to $36 \mathrm{Mg} / \mathrm{ha}$ [4]. So homestead agroforestry have high potentials to carbon sequestration than others strategies. When compare with altitude, the tree biomass $\mathrm{C}$ stock was higher in the high and medium altitude than in the low altitude homestead agro forests, The $\mathrm{C}$ in fallen litter biomass decreased with increasing altitude [32].

\section{Conclusions and Foreword Remarks}

The homestead agro forests have ability to sequester and store atmospheric carbon in the form of woody and leaves biomass and thus help to mitigate negative impacts of climate change. These agro-forests could potentially be a source of carbon credits through an appropriate carbon financing mechanism. The carbon sequestration can be considered permanent because complete biomass removal does not occur from home gardens. Appropriate homestead agro forestry 
practice activities contribute to reducing GHG emissions by avoiding deforestation or improving forest management. They also increase the uptake of atmospheric carbon commonly referred to as carbon storage while communities have built on local coping strategies and adaptive capacities to reduce some extreme climatic vulnerabilities, it is necessary to introduce some forest based structural adaptation measures.

Homesteads agroforestry are the different fruit tree, crops and other livestock forage are practiced for most importance to mitigation and adaptation potential to climate change especially for urban and pre-urban, where the scarcity of land exist. In addition to climate change adaptation and mitigation, it also solves food security problem of the community. One of the most important factors shaping the adaptive capacity of individuals, households and communities with local agro-forests was their access to and control over natural, human, social, physical and financial resources. Resource affecting adaptive capacity includes: (1) human: Local people's knowledge of climate risks, conservation agro forest skills, and enable labour; (2) social: women's savings and loans groups, farmer-based organizations, involving traditional welfare and social support institutions; (3) physical: appropriate infrastructure, seeds and saplings and plantation facilities with skills and training are crucial. So if this all force is coordinated and co-working together on homestead agro forestry practice, so easily to mitigate and adapt climate change.

\section{References}

[1] Ram, R. L., Maji, C., and Bindroo, B. B. (2016). Impact of climate change on sustainable sericultural development in India. International Journal of Agriculture Innovations and Research, 4(6), 2319-147.

[2] Watson, R. T., Noble, I. R., Bolin, B., Ravindranath, N. H., Verardo, D. J., Dokken, D. J. (2000). Land use, land-use change, and forestry. Published for the Intergovernmental Panel on Climate Change by Cambridge University Press, New York.

[3] Lewis, S. L., Edwards, D. P., and Galbraith, D. (2015). Increasing human dominance of tropical forests. Science, 349(6250), 827-832.

[4] Kumar, B. M. (2011). Species richness and aboveground carbon stocks in the homegardens of central Kerala, India. AgricEcosyst Environ., 140(3): 430-440.

[5] Nair, P. K. R., Kumar, B. M., and Nair, V. D. (2009). Agro forestry as a strategy for carbon sequestration. J Plant Nutri Soil Sci., 172: 10-23.

[6] Mattsson. E., Ostwald, M., Nissanka, S. P., and Marambe, B. (2013). Homegardens as a multi-functional land-use strategy in Sri Lanka with focus on carbon sequestration. Ambio. doi:10.1007/s13280-013-0390-x.

[7] Amenu, B. T. (2017). Home-Garden Agro-Forestry Practices and Its Contribution to Rural Livelihood in Dawro Zone Essera District. World, 7(5).

[8] Parihaar, R. S., Bargali, K., and Bargali, S. S. (2015). Status of an indigenous agroforestry system: A case study in Kumaun Himalaya, India. Indian Journal of Agricultural Sciences, 85(3): 442-447.

[9] Miah, M. D. and Hossain, M. K. (2002). 'Tree resources in the floodplain areas of Bangladesh'. Schweizerische Zeitschriftür Forstwesen, 153(10), 385-391.

[10] Sharmin, A. and Ashik Rabbi, S. (2016). Assessment of Farmers' Perception of Agroforestry Practices in Jhenaidah District of Bangladesh. Journal of Agriculture and Ecology Research International, 6(4), 1-10. https://doi.org/10.9734/ JAERI/2016/21760.

[11] Kumar, B. M. and Nair, P. K. R. (2004). 'The enigma of tropical homegardens'. Agroforestry Systems, 61, $135-152$.

[12] Middendorp, R. S., Vanacker, V., and Lambin, E. F. (2018). Impacts of shaded agroforestry management on carbon sequestration, biodiversity and farmers income in cocoa production landscapes. Landscape Ecology, 33(11), pp. 1953-1974.

[13] Hussain, S., Shaobing, P., Fahad, S., Abdul, K., Huang, J., Kehui, C., and Lixiao, N. (2014). Rice management interventions to mitigate greenhouse gas emissions: a review. Environ SciPollut Res. doi: 10.1007/s11356-014-3760-4.

[14] Basak, N. R. (2002). Study on composition of trees in homesteads at different ecological zones in Bangladesh. A Master of Science dissertation in Agro forestry and environment. Department of Agroforestry and Environment, Bangabandhu Sheikh MujiburRahman Agricultural University, Gazipur, Bangladesh Google Scholar.

[15] Singha, S., Uddin, M. S., Banik, S. C., and Kasem, M. A. (2018). Homestead agro forestry systems practiced at Kamalganj Upazila of Moulvibazar District in Bangladesh. Asian Journal of Research in Agriculture and Forestry, pp. 1-8.

[16] Nath, T. K. and Inoue, M. (2014). Contribution of Homestead Forests to Rural Economy and Climate Change Mitigation: A Study from the Ecologically Critical Area of Cox's Bazar Teknaf Peninsula, Bangladesh. https://doi.org/10.1007/s11842-014-9270-x.

[17] Keenan, R. J. (2015). Climate change impacts and adaptation in forest management: a review. Annals of Forest Science, 72(2), pp. 145-167. 
[18] Zegeye, H. (2013). Global climate change: causes, impacts and solutions. In: Workeneh, S., Dechassa, N., Ketema, M., and Belayneh, A. (eds.), Proceedings of the International Conference on Biodiversity Conservation and Ecosystem Services for Climate Change Mitigation and Sustainable Development. Haramaya University (HU), Haramaya and United Nations Development Programme (UNDP). Pp. 2-15.

[19] Termeer, C. J., Dewulf, A., and Biesbroek, G. R. (2017). Transformational change: governance interventions for climate change adaptation from a continuous change perspective. Journal of Environmental Planning and Management, 60(4), pp. 558-576.

[20] Robinson, S. A. (2020). Climate change adaptation in SIDS: A systematic review of the literature pre and post the IPCC Fifth Assessment Report. Wiley Interdisciplinary Reviews: Climate Change, 11(4), p. e653.

[21] Nath, T. K., Aziz, N., and Inoue, M. (2015). Contribution of homestead forests to rural economy and climate change mitigation: a study from the ecologically critical area of Cox’s Bazar Teknaf Peninsula, Bangladesh. Small-Scale Forestry, 14(1), 1-18.

[22] Remling, E. and Veitayaki, J. (2016). Community-based action in Fiji’s Gau Island: a model for the Pacific?. International Journal of Climate Change Strategies and Management.

[23] Baas, S. and S. Ramasamy. (2008). Community Based Adaptation in Action: A Case Study from Bangladesh.

[24] Ussiri, D. A. and Lal, R. (2017). Mitigation of climate change: Introduction. In Carbon Sequestration for Climate Change Mitigation and Adaptation (pp. 287-325). Springer, Cham.

[25] Abbas, F., Hammad, H. M., Fahad, S., Cerdà, A., Rizwan, M., Farhad, W., Ehsan, S., and Bakhat, H. F. (2017). Agroforestry: a sustainable environmental practice for carbon sequestration under the climate change scenariosa review. Environmental Science and Pollution Research, 24(12), pp. 11177-11191.

[26] Ninan, K. N. and Kontoleon, A. (2016). Valuing forest ecosystem services and disservices—Case study of a protected area in India. Ecosystem services, 20, pp. 1-14.

[27] Thomas, S., Dargusch, P., Harrison, S., and Herbohn, J. (2010). Why are there so few afforestation and reforestation clean development mechanism projects? Land Use Policy, 27(3): 880-887.

[28] Shin, M-Y, Miah, M. D., and Lee, K. H. (2007). Potential contribution of the forestry sector in Bangladesh to carbon sequestration. J Environ Manag., 82(1): 260-276.

[29] Haq, M. Z., Robbani, M., Ali, M., Hasan, M. M., Uddin, M. J., Begum, M., da Silva, J. A. T., Pan, X.-Y., and Karim, M. R. (2012). Damage and management of cyclone Sidr-affected homestead tree plantations: a case study from Patuakhali, Bangladesh. Nat Hazard, 64(2): 1305-1322.

[30] Harvey, C. A., Zerbock, O., Papageorgiou, S., and Parra, A. (2010). What is needed to make REDD+ work on the ground? Lessons learned from pilot forest carbon initiatives. Conservation International, Arlington, Virginia, USA. www.conservation.org.

[31] Behera, S. K., Sahu, N., Mishra, A. K., Bargali, S. S., Behera, M. D., and Tuli, R. (2017). Aboveground biomass and carbon stock assessment in Indian tropical deciduous forest and relationship with stand structural attributes. Ecological Engineering, 99, pp. 513-524.

[32] Baul, T. K. T., Akhter, P., R. Nandi, L. H. Schmidt. (2021). Carbon stocks of homestead forests have a mitigation potential to climate change in Bangladesh. Institute of Forestry and Environmental Sciences, University of Chittagong, Chittagong, 4331 Published online 2021 Apr 29. doi: 10.1038/s41598-021-88775-7. 